\title{
An Assessment of Service Quality Dimensions Conducted at Oyo Hotel, Bangalore
}

\author{
Kalavathy. K. S, Swapna. H. R
}

\begin{abstract}
OYO}$, an online hotel booking service organization is getting popularity all over India for their innovative and technology based services. Customers are becoming tech-savvy and are increasingly using Internet for booking hotels online. It is important to know the factors that are determining the consumer's changing behavior. The purpose of the paper is to understand the factors influencing customer's decision to book OYO rooms. An exploratory study using purposive sampling method was carried out. Chi-Square analysis revealed that customer demographics, specifically age, education and occupation play a significant role on customer usage frequency. The study aids in giving an additional insight to understand consumer behavior in online hotel booking services and to understand the need for assessment of service quality to deliver the expected service.
\end{abstract}

Keywords : Customer Satisfaction, Service Quality, Service Dimension.

\section{INTRODUCTION}

The hospitality industry is a broad group of businesses that provide services to customers. It is focused on the satisfaction of customers and providing specific experiences for them. The hotel industry in Bangalore thrives largely because of the growth in tourism and travel. There is a considerable growth in tourism due to the raise in foreign and domestic tourists. International companies are also gradually looking at setting up such hotels in Bangalore. With the rise in the middle class and disposable income, the tourism and hospitality sector is witnessing a healthy growth and accounts for 7.5 percent of the country's GDP (Starkov. M \& Safer M.M., 2010).

The revolution of E-Commerce industry enhances the growth and potential business opportunities of the online tourism market. With the emerging online travel booking, an operator has become a global phenomenon and represents one third of total global travel sales (Anckar B. and Walden P., 2002). According to octane research, consumers are utilizing the internet to

Revised Manuscript Received on September 22, 2019.

* Correspondence Author

Dr.Kalavathy.K.S, Associate Professor, The Oxford College of Business Management, Bangalore, India.

Dr.Swapna.H.R, Associate Professor, The Oxford College of Busines Management, Bangalore, India take advantage of easy booking. With the help of comparative pricing $95 \%$ of consumers search online before making a travel purchase. Best deals are an important motivation for customers to book online (Beldona S., Nusair K. and Demicco F., ). Since the online agencies provide flexibility and accessibility, it is easy for tourists to search and buy travel services within a small fraction of time.

Online consumers tend to utilize numerous websites like Yatra, Cleartrip, Trivago, Goibibo, Expedia etc. as a primary tool for booking travel services due to the variety of product offerings, time savings, quick price comparisons and ease of use when requesting services to fulfill their needs. Online booking option not only benefits customers by making travel arrangements easier, it also increases the profits of businesses such as airlines, hotels and other package tour companies. Research shows 32\% of hotel revenue is generated through online bookings (Patricia Dodu Silvia, 2008). The travel intermediaries consist of third-party travel agencies (e.g., Bookmyhotel.com), search engines (e.g., Google, yahoo) and social media sites (e.g., Yatra.com). Most consumers are concerned with attaining good value for their money instead of solely seeking the lowest possible price (Rosen and Wilde, 2000).

With a rise in online booking, there is a huge competition within them hence popular models have come up with online travel agents (OTAs) offering a single marketplace for all travel-related needs. There are search engines like MakeMyTrip and Trip Advisor, that operate like travel discovery platforms. Further, online accommodation reservation services like Oyo Rooms have gained popularity. Apart from this, branded hotels are seen operating direct bookings through their websites.

OYO rooms, commonly known as OYO, is India's first technology driven network of standardized branded budget hotels in the country. It started in 2012 and currently it is a chain of hotels and its goal is to change the way people stay away from home.OYO is providing variety of hotel rooms, flagship, studio stays, long stays

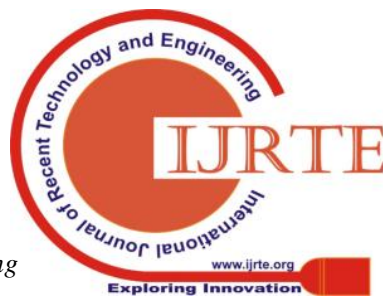


and oyo bazaar to the customers (Dr. Namrata Maheshwari, Dr. Jesu A. Kundailaraj, 2018).

Organizations today are interested in providing top quality customer service to their clients. Over 20 billion customer satisfaction surveys are conducted on an annual basis around the world to understand what customers want from their experience and how well they perform against delivering on those expectations (Sharma Deependra, 2016).

Understanding client needs is an initial stage for delivering superior service. Customers will compare their service perceptions against their expectations when judging the quality of an organization's service delivery. Organizations must know who are their clients, what they experience now, and what they want in the future service experiences. In addition, the stability of those expectations and how quickly they change over time or vary across service situations and client groups must also be closely examined.

Guests view the quality of the service as successful or failure, depending on to the impact of the service they have experienced. Since hotels are of offering intangible and perishable personal service encounters, managing these services are a primary concern of any hotel business.

\section{THEORETICAL BACKGROUND OF THE STUDY}

Service quality is measured by customer satisfaction audits, where customers either rate satisfaction on an ordinal scale or give verbal feedback on their experience of the service (or a combination of both) (Arrunade,2000). This has often proved to be helpful for the organizations as they get to know whether they are doing right.

For instance, customers at a high end restaurant will have a great focus on the tangibles whereas at a doctor's surgery they will have a strong focus on empathy, and a train operator might be tasked with reliability. This is not to say other dimensions are not important but just, how customers place their prominence.

The five elements i.e., Reliability, Responsiveness, Assurance, Empathy and Tangibles create a holistic view of any service environment; firstly the tangible aspects of the environment must look right. Note that 'right' does not necessarily mean that it should be luxuriously appointed in all cases; a fast-food outlet needs primarily to look clean and deficient, although not implying to a customer that a lot of money has been spent on excessive luxury. (Valarie A. Zeithaml, 2010)

The five dimensions of service quality are:

[Source: Parasuraman, Zeithame and Berry, 1988] Tangibility
Customers derive their perception of service quality by comparing the tangibles associated with the services provided. It includes the appearance of the physical facilities, equipment and communication materials.

\section{Reliability}

It is the ability to perform the promised service accurately and dependably. Reliability means how efficiently the company delivers on its promises. Customers want to associate with companies that keep their promises, particularly about the service outcomes and core service attributes. Firms that do not provide the core service that customers expect tend to lose their customers in the most direct way.

\section{Responsiveness}

It is the enthusiasm to help customers and provide prompt service. The dimension emphasizes on attentiveness and promptness in dealing with customer's requests, questions, complaints and problems. Responsiveness is calculated by the length of time they have to wait for assistance, answers to questions or attention to problems. Responsiveness is also calculated by the flexibility and ability to customize the service to customer needs.

\section{Assurance}

It is the courtesy and knowledge of employees and their ability to convey confidence and trust. Trust and confidence may be dependent on the person who links the customer to the company, for example, the marketing department. Thus, employees are aware of the importance to create trust and confidence for the customers to gain competitive advantage and for customers' loyalty.

\section{Empathy}

It means caring and attention the firm provides its customers. Empathy is an important dimension to increase the customer's loyalty. In this competitive world, the customer's requirements are rising day after day and it is the companies are trying their maximum to meet the demands of customers, else customers who do not receive individual attention will search elsewhere.

\section{IMPORTANCE OF THE STUDY}

Since Indian social, cultural and economic environment is changing rapidly; customer's preferences and expectations are bound to witness change. This changing environment has made it imperative to study about customer's likes and preferences time to time. Customers will compare their service perceptions against their expectations for judging the quality of a service organization. Hence it is important to study about what customers expect, think and feel about the quality of services rendered to them, which helps the management to know what the customers expect and where they stand in terms of services rendered

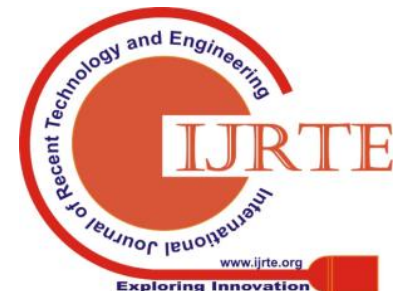


to them. It is necessary for the management to provide what the customer expect as it leads to customer satisfaction which in turn leads to customer loyalty.

\section{NEED FOR THE STUDY}

Service quality dimensions help the management to examine whether the planned service matches with the actual service. It ultimately helps the management to know the actual service delivered to the customers and necessary actions to be taken to provide customer delight experience by knowing what kind of service is exactly expected by the customers (Agarwal and Gulshan Kumar, 2016). This study includes an examination of various service quality dimensions i.e, Reliability, Responsiveness, Assurance, Empathy and Tangibles with reference to OYO Boutique Hotel.

\section{REVIEW OF LITERATURE}

Various research studies related to the topic are reviewed and presented below.

Alauddin, Syed, Masrurul, Islam and Musharof (2019), attempts to reveal the relationship between service quality, customer satisfaction and customer loyalty of the hotel sector in Bangladesh. A total of one hundred native and international tourists are selected for the study. The self-employed form survey was used to gather information from the respondents by using SERVQUAL model. The relationship between the variables was studied by applying Pearson Correlation analysis. Results indicate that a significant relationship exist between service quality attributes and customer satisfaction. Results conjointly revealed that service quality results in satisfying customers and customers' satisfaction results in customer loyalty.

Akhila and Manikandan (2018) in their research titled 'A study on growing trends of online hotel booking', have highlighted the emergence of Indian tourism and hospitality industry as one of the key drivers of growth among the services sector in India. Hospitality is the relationship between a guest and a host. Hospitality is the act or practice of being hospitable. Tourism and hospitality industry are related to each other. The study is framed to analyze the usage of online platforms to book hotels online spread across South of India. It is an attempt to draw out results from the online hotel booking users, awareness on online hotel booking, and their satisfaction levels and to measure their priorities while booking a hotel online. With the introduction of peer to peer hospitality services which will bring a potential dynamic dimension to the hospitality industry, the study aims to find out whether the online users will prefer the community based hospitality services or not.
Ramesh (2017) in his research titled 'Mapping service quality in hospitality industry: A case through SERVQUAL', has proposed a research framework to assess service quality and customer satisfaction in hospitality industry. The study is conducted in case study format and data is collected from hotel guests through self-administered questionnaire while check-in and check-out. The result of the study illustrates that service quality can significantly influence the satisfaction level of hotel guests. It is found that guest's expectations are consistently not met when measured on redesigned five dimensions SERVQUAL at candidate hotel. Tangibility and Empathy are mainly underperforming dimensions where managerial focus must increase. Relatively candidate hotel performed well on Responsiveness dimension.

Nguyen (2017) proposed that the customers' loyalty of hotel services in the world is abundant but in the field of hotel industry in Vietnam is very little. The paper will provide a review of the models that evaluate the customers' loyalty in the hotel service in the world for proposing a model in Viet Nam. In general, through the approach and viewpoint of the researchers in different countries in the field, the author found that many factors have been shown to have a direct or indirect impact on loyalty, therefore, the determination of the factors are only relative and can vary based on space and time. The researcher has proposed a research model of factors including Perceived Quality (including both Tangible's Perception and Intangibles' Perception), Perceived Value, Brand, Customer Relationship Management, and Satisfaction that may affect to the customers loyalty in hotel services in Vietnam.

\section{RESEARCH DESIGN}

The research design is a blue print prepared to provide necessary direction for research. It includes statement of the problem, objectives, sampling size and tools for data analysis. (Kothari C.R.,1990).

\section{STATEMENT OF THE PROBLEM}

Service quality plays a critical role for service firms to position themselves strongly in a competitive environment which is also an indicator of business performance. The research is done to analyze the quality of the services being provided by OYO rooms. Management seeks to know the level at which their customers are satisfied with their services and the level of service quality customers would like in order to offer exactly what they wish for. Evaluation of OYO service quality will be based on five dimensions, i.e, Reliability, Responsiveness, Assurance, Empathy and 
Tangibles. Improvement in the quality of services requires identification of the service quality attributes that are important to retain customers. However, it is important to meet, maintain and exceed the customers' expectations in order to retain customer's loyalty through high service quality.

\section{SCOPE OF THE STUDY}

Service organization's main goal is customer loyalty. With the help of service quality dimensions, the offered service can be evaluated by customers who help the management to know the exact service delivered by them to the customers. It also helps to provide delightful experience by knowing what kind of service is exactly expected by the customers with the help of service quality dimensions (Reliability, Responsiveness, Assurance, Empathy and Tangibles). By tracing the socio-demographic profile of the customers the marketers can make strategy to attract those segments which are lagging behind from using OYO rooms in Bangalore.

\section{OBJECTIVES OF THE STUDY}

- To examine the various service quality dimensions with reference to OYO Boutique Hotel in Bangalore.

- To identifying the effects of the OYO Customer' $\mathrm{s}$ demographic variables on respondent' s frequency of use of services

Table 1: Demographic Profile of the Respondents

\begin{tabular}{|c|c|c|c|}
\hline \multicolumn{2}{|c|}{ CHARACTERISTICS } & \multirow{2}{*}{$\begin{array}{c}\text { NO. } \begin{array}{c}\text { OF } \\
\text { RESPONDENTS }\end{array} \\
66 \\
\end{array}$} & \multirow{2}{*}{$\begin{array}{c}\text { PERCENTAGE OF } \\
\text { RESPONDENTS } \\
66 \%\end{array}$} \\
\hline \multirow{2}{*}{ GENDER } & MALE & & \\
\hline & FEMALE & 34 & $34 \%$ \\
\hline \multirow[t]{5}{*}{ AGE (Years) } & $<20$ & 15 & $15 \%$ \\
\hline & $21-30$ & 51 & $51 \%$ \\
\hline & $31-40$ & 27 & $27 \%$ \\
\hline & $41-50$ & 3 & $3 \%$ \\
\hline & $>50$ & 4 & $4 \%$ \\
\hline \multirow[t]{4}{*}{ EDUCATION } & $12^{\text {th }} / \mathrm{PUC}$ & 15 & $15 \%$ \\
\hline & Graduate & 38 & $38 \%$ \\
\hline & Post Graduate & 41 & $41 \%$ \\
\hline & Other & 6 & $6 \%$ \\
\hline \multirow[t]{5}{*}{ INCOME /MONTH (Rs.) } & $<20,000$ & 11 & $11 \%$ \\
\hline & $21,000-40,000$ & 42 & $40 \%$ \\
\hline & $41,000-60,000$ & 31 & $31 \%$ \\
\hline & $61,000-80,000$ & 10 & $10 \%$ \\
\hline & $>81,000$ & 6 & $6 \%$ \\
\hline \multirow[t]{4}{*}{ OCCUPATION } & Self Employed & 10 & $10 \%$ \\
\hline & Salaried & 32 & $32 \%$ \\
\hline & Professional & 37 & $37 \%$ \\
\hline & others & 21 & $21 \%$ \\
\hline \multirow[t]{3}{*}{ FREQUENCY OF USAGE } & $\begin{array}{c}\text { Light users }(<3 \\
\text { times/year) }\end{array}$ & 24 & $24 \%$ \\
\hline & $\begin{array}{c}\text { Medium users(3-5 } \\
\text { times/year) }\end{array}$ & 35 & $34 \%$ \\
\hline & $\begin{array}{l}\text { Heavy users } \\
(>5 \text { times/year) }\end{array}$ & 41 & $41 \%$ \\
\hline
\end{tabular}

- To ascertain which aspect of service quality has a significant impact on customer satisfaction with respect to demographic factors.

\section{HYPOTHESIS}

- There is no significant impact with regards to demographic variables and customer satisfaction levels.

- There is no significant difference across different service dimensions with respect to customer satisfaction.

\section{SAMPLING FRAMEWORK}

Purposive sampling method has been used to select a sample size of 100 customers who have used OYO services at Bangalore. Both primary and secondary data have been used for data collection.

\section{DATA ANALYSIS AND INTERPRETATION}

The description of the demographic profile of the respondents considered in the study is given below. The demographic factors namely age, gender, education, occupation and income of respondents are considered here. 
Table 1 shows that out of 100 samples collected, 66 were male respondents and 34 were female respondents. It is also noted that $15 \%$ of the respondents are of age below 20 years, $51 \%$ of the respondents are of age group $21-30$ years, $27 \%$ of the respondents are of the age group 31-40 years, $3 \%$ of the respondents are of the age group 41-50 years, and $4 \%$ are of the age group above 50 years.

From the above table it can be inferred that $10 \%$ of the respondents are Self Employed, 32\% of the respondents are Self Employed, $37 \%$ of the respondents are Professional and $21 \%$ respondents are into other occupations. It can also be inferred that $11 \%$ of the travelers are earning below 20000 per month, $40 \%$ of the travelers earn 21000-40000 per month, $31 \%$ of the travelers earn $41000-60000$ per month, $10 \%$ of the travelers earn $61000-80000$ per month, $6 \%$ of the travelers earn more than 81000 per month. From the above table it can be understood that $15 \%$ respondents have educational qualification of $12 \mathrm{th} / \mathrm{PUC}, 38 \%$ respondents are graduates and $41 \%$ respondents are post-graduates and $6 \%$ belong to others. $24 \%$ of the respondents are light users of OYO hotel services, $35 \%$ of the respondents are medium users and around $41 \%$ of the respondents are heavy users of OYO services.

We continue to our second research objective which relates to identifying the effects of the OYO Customers ${ }^{\text {ec }}$ characteristics on his/her frequency of use of services. For that, relevant Cross-tabulations using Chi-Square tests were conducted. A composite table depicting the implications of Demographic variables on frequency of use is presented in Table 2 which is being followed by the explanations from Chi- Square analysis.

Table 2: Composite Table Depicting the Relationship of the Satisfaction with Frequency of Use OYO Room Services

\begin{tabular}{|c|c|c|c|c|c|}
\hline Demographics & Details & Frequency & d.f. & Chi. Sq. Value & Sig.* \\
\hline \multirow[t]{2}{*}{ GENDER } & MALE & 66 & \multirow[t]{2}{*}{2} & \multirow[t]{2}{*}{24.645} & \multirow[t]{2}{*}{$0.321 *$} \\
\hline & FEMALE & 34 & & & \\
\hline \multirow[t]{5}{*}{ AGE (Years) } & $<20$ & 15 & \multirow[t]{5}{*}{6} & \multirow[t]{5}{*}{6.187} & \multirow[t]{5}{*}{$0.000 *$} \\
\hline & $21-30$ & 51 & & & \\
\hline & $31-40$ & 27 & & & \\
\hline & $41-50$ & 3 & & & \\
\hline & $>50$ & 4 & & & \\
\hline \multirow[t]{4}{*}{ EDU LEVEL } & $12^{\text {th }} / \mathrm{PUC}$ & 15 & \multirow[t]{4}{*}{6} & \multirow[t]{4}{*}{9.108} & \multirow[t]{4}{*}{$0.000^{*}$} \\
\hline & Graduate & 38 & & & \\
\hline & Post Graduate & 41 & & & \\
\hline & Other & 6 & & & \\
\hline \multirow{5}{*}{$\begin{array}{c}\text { INCOME/ MONTH } \\
\text { (Rs) }\end{array}$} & $<20,000$ & 11 & \multirow[t]{5}{*}{6} & \multirow[t]{5}{*}{12.438} & \multirow[t]{5}{*}{$0.05^{*}$} \\
\hline & $21,000-40,000$ & 42 & & & \\
\hline & $41,000-60,000$ & 31 & & & \\
\hline & $61,000-80,000$ & 10 & & & \\
\hline & $>81,000$ & 6 & & & \\
\hline \multirow{4}{*}{ OCCUPATION } & Self Employed & 10 & \multirow[t]{4}{*}{4} & \multirow[t]{4}{*}{9.542} & \multirow[t]{4}{*}{$0.026^{*}$} \\
\hline & Salaried & 32 & & & \\
\hline & Professional & 37 & & & \\
\hline & others & 21 & & & \\
\hline
\end{tabular}

As per the analysis depicted in the above table 2, Age, Occupation and Education level have a significant influence on frequency of use. On the contrary, Gender and income doesn't have any significant influence on customer's satisfaction.

Service Quality and Customer Satisfaction Relationship Analysis
The correlation analysis was used to find the strength of the relationship between service quality and customer satisfaction. The results of Pearson correlation (table no.3) show that dimensions of service quality are positively associated with customer satisfaction.

Table 3: Correlation: Service Quality and Customer Satisfaction

\begin{tabular}{|l|l|l|l|l|l|}
\hline & Tangibles & Reliability & Responsiveness & Assurance & Empathy \\
\hline $\begin{array}{l}\text { Customer } \\
\text { Satisfaction }\end{array}$ & 0.694 & 0.367 & 0.760 & 0.540 & 0.630 \\
\hline
\end{tabular}


Among all the five service dimensions responsiveness (.760) is the factor which influences customer satisfaction the most followed by Tangibles (.694), Empathy (.630), Assurance (.540) and Reliability (.367).

\section{FINDINGS AND SUGGESTIONS}

According to the analysis, Age, Occupation and Education level have a significant influence on customer's satisfaction and hence influence the decision making to avail the services of OYO rooms. Gender and income doesn't have any significant influence on customer's satisfaction towards OYO rooms. Men avail the services of OYO rooms more frequently. Respondents in the age group of 21-40 years, Professionals and salaried respondents avail the services more frequently. They are using OYO rooms because of reasonable prices. Among all the five service dimensions, responsiveness is the factor which influences customer satisfaction the most. $58 \%$ of the travelers stay at hotel during their vacation and would like to spend their leisure time effectively in exploring places.

It is important to study about what customers expect, think and feel about the quality of services rendered. It helps the management to know what guests expect and serve the expectations. It helps in evaluating the services and knows where they stand in terms of services rendered to them and take necessary actions to meet the expectations. Each dimensions of service quality should be given equal importance and should take necessary actions to improve them. On other hand to gain more loyal customers, recruiting the most promising employees, measuring and rewarding employees for delivering service with excellence, provide them with on-going training in interpersonal and problem-solving skills.

Management should have better knowledge on expected service and delivered service. Should initiate feedback and should take steps for providing expected service to the customers. Responsiveness factor has been accorded a very high level of importance by the respondents, since the employee's play a very important role in influencing this factor; they have to be adequately trained to provide excellent service. The tangible component of service providers can be strengthened by quality food and beverages offered through latest facilities in the hotel.

It is understood that respondents would prefer travelling during vacation. Hence marketers should increase their promotion during vacation time to attract the travelers. Marketers should use social networks for advertising as social networks have emerged as a very important source for creating awareness. Social networks can also be used further to influence customers through advertising and positive word of mouth.

Providing a high-quality service experience requires an organization to recruit the most promising employees, measure and reward employees for delivering service with excellence, provide them with on-going training in interpersonal and problem-solving skills, and measure and reward employees for delivering service with excellence.

\section{CONCLUSION}

The study develops better understanding of customer's decision making factors in context of services rendered by online hotel booking services. The findings reveal that by focusing on service dimensions and quality services, OYO service vendors can easily and effectively retain customers. The research showed that the satisfaction level will enhance customer's frequency of usage. The demographic factors are significantly affecting the frequency of usage. The research will help the service providers to have a comprehensive, holistic and clearer understanding of factors that influence the satisfaction level of Indian consumers.

\section{REFERENCES}

1. Agarwal A, Kumar G (2016), "Identify The Need for Developing a New Service Quality Model in Today's Scenario: A Review of Service Quality Models", Arabian J Bus Managerial Review, Volume 6, pp193.

2. Alauddin, Syed, Masrurul, Islam and Musharof(2019), 'Investigating the Relationship between Service Quality, Customer Satisfaction and Customer Loyalty in Hotel Industry: Bangladesh Perspective', Globa Journal of Management and Business Research: A Administration and Management Volume 19 Issue 1 Version 1.0

3. Anckar B. and Walden P., (2002), "Self-booking of high and low complexity travel products: exploratory findings", Journal of Information Technology and Tourism, Volume 4, Issue 1, 151-165.

4. Arrunada Benito (June 2000), "Audit Quality: Attributes, Private Safeguards and the Role of Regulation", The European Accounting Review, 9(2), 205-224.

5. Beldona S., Nusair K. and Demicco F., (2009). "Online travel purchase behavior of generational cohorts: A longitudinal study", Journal of Hospitality Marketing and Management, Volume 18,Issue 1,406-420.

6. Dr. Namrata Maheshwari, Dr. Jesu A. Kundailaraj, (2018), 'Determining The Factors Affecting Customers Satisfaction In Oyo Rooms', Journal of Emerging Technologies and Innovative Research (JETIR), February 2018, Volume 5, Issue 2.

7. Dr. Ramesh Kumar Chaturvedi (2017), 'Mapping Service Quality in Hospitality Industry: A Case through SERVQUAL', A \& V Publications.

8. Kothari C.R (1990), 'Research Methodology Methods and techniques', Second edition.

9. Kotler P (2002), 'Marketing management', New Jersey: Pearson Education

10. Nguyen Thi Thanh Xuan (2017), 'A Review of Customer Loyalty Models in Hotel Services and Research Model in Vietnam', International Journal of Management Research \& Review, Vol: 3 Issue: 1

11. Parasuraman, Zeithame and Berry, (1988), "SERVQUAL: A MultipleItem Scale for Measuring Consumer perceptions of Service Quality", Journal of Retailing, Volume 64, Issue-1.

12. Patricia Dodu Silvia, (2008), "The internet, threat or tool for travel agencies?" , Annals of the University of Oradea, Economic Science Series, Volume 17, Issue 2

13. Rosen Cheryl, Wilde Candee, (November 13, 2000), "Travel agents haven't proven they can beat the internet threat- up in the air", Information Week, Gale-British Council Library

14. S Akhila and C Manikandan (2018), 'A study on growing trends of online hotel booking', International Journal of Commerce and Management, Volume 4; Issue 3; Page No. 09-15.

15. Sharma Deependra, (August 2016),"Enhancing customer experience using technological innovations", Worldwide Hospitality and Tourism Themes, Vol. 8 Issue 4, 469 - 480

16. Starkov, M; Safer M.M. (2010) Top Ten Internet Marketing Resolutions Hospitality e-Business $\quad$ Strategies http://www.hospitalityebusiness.com/ articles.php, downloaded February 15th 2010.

17. Valarie A. Zeithaml (2010), 'Service Marketing', McGraw Hill Education, Seventh edition.

18. https:/oyorooms.com

19. https://marketingmix.co.uk/promotion 